\title{
Selective Separation-Flotation of Hafnium from Zirconium and Their Determination in Real Samples
}

\author{
M. A. KabiLI, ${ }^{\dagger}$ M. A. AKL, A. M. AbDallah, and D. S. IsmaIl \\ Department of Chemistry, Faculty of Science, University of Mansoura, P. O. Box 15 Mansoura, Egypt
}

\begin{abstract}
A simple procedure is presented for selective separation of hafnium from zirconium in both simulated and real samples. The procedure depends on using Alizarin Red sulfonate (ARS) for complexation of both $\mathrm{Hf}(\mathrm{IV})$ and $\mathrm{Zr}(\mathrm{IV})$, in which a flotation step is applied for floating their complexes using oleic acid (HOL) surfactant. Several factors affecting the flotation process have been studied. It is found that hydrogen ion concentration is of paramount importance. Maximum separation of $\mathrm{Zr}(\mathrm{IV})(100 \%)$ is achieved at $\mathrm{pH}$ range $1.5-2$, whereas at $\mathrm{pH}$ range $5.5-7 \mathrm{Hf}(\mathrm{IV})$ is completely separated. Interference of various foreign ions is avoided by adding excess ARS. Infra-red data were used for suggesting the flotation mechanism.
\end{abstract}

(Received November 26, 1999; Accepted March 9, 2000)

\section{Introduction}

Zirconium and hafnium occur in nature principally as the mineral zircon $\left(\mathrm{ZrSiO}_{4}\right)$. Because of its beauty and hardness the mineral is used as a semiprecious stone. Zirconium is used for removing sulfur, nitrogen and oxygen from steel, in the ceramic industry to produce enamels, ${ }^{1}$ in the manufacture of copper and its alloys and in the production of optical glasses with high refractive index. Due to lanthanide contraction, zirconium and hafnium are very similar in chemistry and occur together in nature. Nuclear reactors require hafnium free zirconium for controlling and protecting the devices, so both pure $\mathrm{Zr}(\mathrm{IV})$ and $\mathrm{Hf}(\mathrm{IV})$ should be available. Because of hafnium's rarity and difficulty of separating hafnium from zirconium, the chemistry of hafnium has not been investigated in detail. ${ }^{2}$ Accordingly separation of hafnium from zirconium is a vital process.

Hafnium is found in nature, in all zirconium minerals, in the range of fractions of a percent of zirconium content. Separation of the two elements is extremely difficult, even more so than for adjacent lanthanides. ${ }^{3}$ The first separation of $\mathrm{Hf}(\mathrm{IV})$ and $\mathrm{Zr}(\mathrm{IV})$ was carried out by Coster and Hevesy. ${ }^{4}$ Solvent extraction, ${ }^{5}$ ion flotation $^{6}$ and froth flotation ${ }^{7}$ techniques were used for the separation of $\mathrm{Zr}(\mathrm{IV})$ and $\mathrm{Hf}(\mathrm{IV})$. Most of these methods have some limitations in which poor selectivity is obtained with relatively low recovery. Also most of the reported spectrophotometric methods in the literature give the total content of $\mathrm{Zr}(\mathrm{IV})$ and $\mathrm{Hf}(\mathrm{IV})$ at the same time. ${ }^{8-14}$ Consequent to the need of large scale separation with the determination of each element alone, relatively new techniques should be developed.

Consideration of the foregoing led us to focus attention on the flotation technique for selective separation of $\mathrm{Hf}(\mathrm{IV})$ from $\mathrm{Zr}(\mathrm{IV})$ in real samples. This technique has become of considerable interest in recent years owing to its simplicity, adaptability to the removal of traces of heavy metals from industrial effluents ${ }^{15,16}$ and to the preconcentration-determination

† To whom correspondence should be addressed. of trace substances. ${ }^{17,18}$ The proposed procedure (solvent sublation technique) was used for the selective separation of micro amounts of $\mathrm{Zr}(\mathrm{IV})$ and $\mathrm{Hf}(\mathrm{IV})$ through the formation of a stable soluble complex with the collector (ARS) in the HOL layer. The procedure need simple apparatus and less experimental skill and is more reliable and rapid.

\section{Experimental}

Reagents

All reagents were of analytical reagent grade. The stock solution of $\mathrm{Zr}(\mathrm{IV})(1 \mathrm{mg} / \mathrm{ml})$ was prepared by dissolving 3.531 $\mathrm{g}$ of zirconyl chloride octahydrate in a few milliliters of $2.0 \mathrm{~mol}$ $\mathrm{l}^{-1} \mathrm{HCl}$ and diluted to 11 with the acid. The stock solution of $\mathrm{Hf}$ (IV) $(1 \mathrm{mg} / \mathrm{ml})$ was prepared by fusing $1.179 \mathrm{~g}$ of $\mathrm{HfO}_{2}$ with $\mathrm{Na}_{2} \mathrm{CO}_{3}$ and the melt was dissolved in doubly-distilled water to 11. Alizarin Red sulfonate $\left(1 \times 10^{-2} \mathrm{~mol} \mathrm{l}^{-1}\right)$ stock solution was prepared by dissolving $3.603 \mathrm{~g}$ in 11 of doubly distilled water. Arsinazo III stock solution was prepared by dissolving $5 \mathrm{~g}$ in 11 of doubly distilled water. Tartaric acid stock solution was prepared by dissolving $10 \mathrm{~g}$ in $100 \mathrm{ml}$ of doubly distilled water. Oleic acid stock solution $\left(6.36 \times 10^{-2} \mathrm{~mol} \mathrm{l}^{-1}\right)$ was prepared by dispersing $20 \mathrm{ml}$ of HOL (food grade, sp. gr. 0.895 provided from J. T. Baker Chemical Co.) in 11 of kerosene. The real samples of zirconium and hafnium ores were obtained from the National Institute of Metallurgy, South Africa.

\section{Apparatus}

The flotation cell used was a cylindrical graduated glass tube of $16 \mathrm{~mm}$ inner diameter and $290 \mathrm{~mm}$ length with a stopper at the top and a stopcock at the bottom. The spectral data were recorded on Unicam UV $2100 \mathrm{UV} / \mathrm{V}$ is and MATTSON 5000 FTIR spectrometers. The $\mathrm{pH}$ values of all solutions were measured using Hanna Instruments 8519 digital pH meters.

Separation and determination procedure of $\mathrm{Zr}(\mathrm{IV})$ and $H f(I V)$

Suitable concentrations of $\mathrm{Zr}(\mathrm{IV}), \mathrm{Hf}(\mathrm{IV})\left(5 \times 10^{-4} \mathrm{~mol} \mathrm{l}^{-1}\right.$, each) and ARS $\left(5 \times 10^{-3} \mathrm{~mol} \mathrm{l}^{-1}\right)$ were mixed; then $3 \mathrm{ml}$ doubly- 


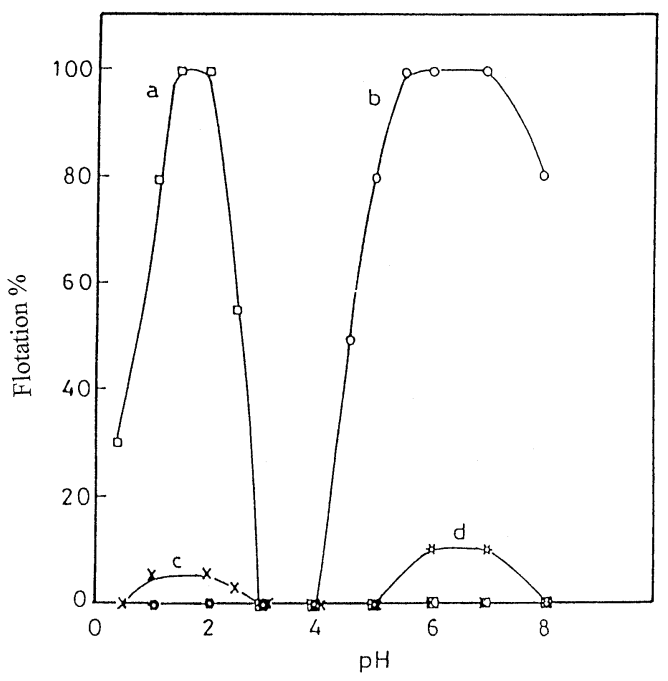

Fig. 1 The role of hydrogen ion concentration on the selective separation-flotation of $5 \times 10^{-5} \mathrm{~mol} \mathrm{l}^{-1}$ of $\mathrm{Zr}(\mathrm{IV})$ and $\mathrm{Hf}(\mathrm{IV})$ in an admixture using $2 \times 10^{-4} \mathrm{~mol} \mathrm{l}^{-1} \mathrm{HOL}$ in the presence and absence of $5 \times 10^{-4} \mathrm{~mol} \mathrm{l}^{-1}$ ARS. a. Zr(IV) + ARS + HOL. b. Hf(IV) + ARS + HOL. c. $\mathrm{Zr}(\mathrm{IV})+\mathrm{HOL}$. d. Hf(IV) $+\mathrm{HOL}$.

distilled water was added. The $\mathrm{pH}$ was adjusted at $1.5-2$. The solution was then transferred quantitatively to the flotation cell and completed to $10 \mathrm{ml}$ with doubly distilled water. The cell was shaken well for a few seconds to ensure complete complexation. To this solution, $3 \mathrm{ml}$ of $2 \times 10^{-4} \mathrm{~mol} \mathrm{l}^{-1} \mathrm{HOL}$ was added. The flotation cell was then inverted upside down twenty times by hand. After $10 \mathrm{~min}$, for complete flotation, the mother liquor (containing Hf) was completely rinsed into another flotation cell. The scum layer in the first flotation cell, containing $\mathrm{Zr}(\mathrm{IV})$, was treated with concentrated $\mathrm{HNO}_{3}(\sim 2 \mathrm{ml})$ for eluting $\mathrm{Zr}(\mathrm{IV})$ in which the latter is determined spectrophotometrically using $1 \mathrm{ml}$ of $0.05 \%$ aqueous solution of Arsenazo III at $665 \mathrm{~nm}^{8}$ The $\mathrm{pH}$ of the mother liquor in the second flotation cell was raised to $5.5-7$ by adding two drops of $\mathrm{NaOH}\left(\sim 0.1 \mathrm{~mol} \mathrm{l}^{-1}\right)$ and the previous steps for flotation, metal elution and spectrophotometric determination were carried out. The floatability $(F \%)$ of the analytes was calculated from their concentrations after and before separation.

$$
F=\frac{c_{\mathrm{f}}}{c_{\mathrm{i}}} \times 100 \%
$$

where $c_{\mathrm{f}}$ and $c_{\mathrm{i}}$ denote the concentrations of the analyte after and before flotation, respectively.

\section{Results and Discussion}

Separation and micro determination of zirconium and hafnium: separation-floatation

In solvent sublation technique oleic acid imposed itself as an excellent surfactant for selective separation of some metal ions as solid colored precipitate in the scum layer. ${ }^{19-25}$

A series of experiments was carried out to float zirconium and hafnium each individually or in combination using HOL alone. Suitable concentration of each analyte $\left(5 \times 10^{-5} \mathrm{~mol} \mathrm{l}^{-1}\right)$ was taken in the flotation cell and a sufficient quantity of $\mathrm{HOL}$ surfactant $\left(2 \times 10^{-4} \mathrm{~mol}^{-1}\right)$ which was still less than the critical micelle concentration (CMC), was added to float zirconium and

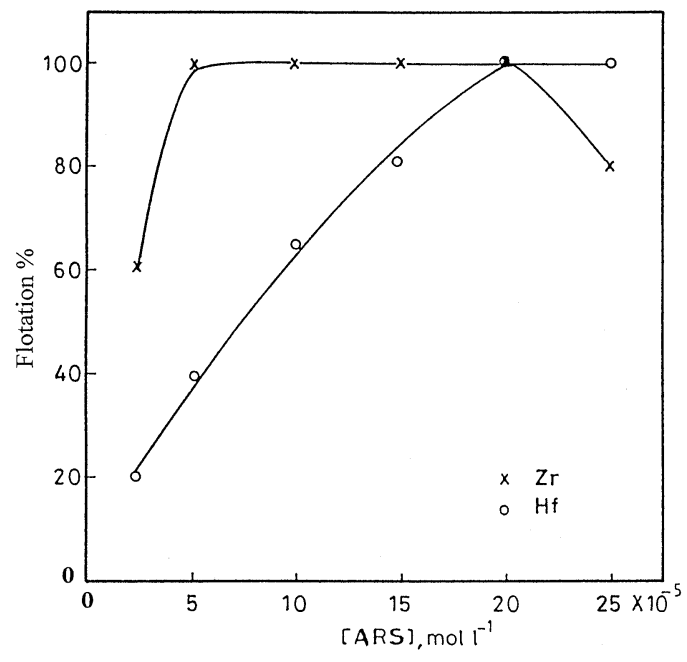

Fig. 2 Influence of ARS concentration on the floatability of $5 \times$ $10^{-5} \mathrm{~mol} \mathrm{l}^{-1} \mathrm{Zr}(\mathrm{IV})$ at $\mathrm{pH} 1.5$ and $\mathrm{Hf}(\mathrm{IV})$ at $\mathrm{pH} 6$ using $2 \times 10^{-4} \mathrm{~mol}$ $1^{-1}$ HOL.

hafnium at different hydrogen ion concentrations. The data in Fig. 1 (curves c \& d) prove that not more than $10 \%$ of each analyte were separated at any $\mathrm{pH}$. These results were obtained whatever acid was used. Such separation percentage is not analytically satisfactory, though zirconium and hafnium float as metal oleates. Accordingly, many trials were carried out to separate zirconium quantitatively and selectively from hafnium using different organic collectors. Of these, ARS imposed itself as an excellent collector. The data in Fig. 1 (curves a \& b) show that selective and complete separation $(\approx 100 \%)$ of $\mathrm{Zr}(\mathrm{IV})$ and Hf(IV) was obtained in $1.5-2$ and $5.5-7 \mathrm{pH}$ ranges, respectively in the presence of $5 \times 10^{-4} \mathrm{~mol} \mathrm{l}^{-1}$ ARS. Consequently, further experiments were carried out at $\mathrm{pH} 1.5$ and 6 for $\mathrm{Zr}(\mathrm{IV})$ and $\mathrm{Hf}(\mathrm{IV})$, respectively.

A literature survey ${ }^{26,27}$ showed that $\mathrm{Zr}(\mathrm{IV})$ and $\mathrm{Hf}(\mathrm{IV})$ form 1:1 complexes with ARS at low $\mathrm{pH}(0.5-1)$. As the $\mathrm{pH}$ increases other species $(1: 2,1: 3, \ldots)$ are formed. To select the suitable concentration of the collector (ARS) required for quantitative separation of each element, other series of experiments were carried out. The data in Fig. 2 show the floatability of $\mathrm{Zr}(\mathrm{IV})$ increases reaching $100 \%$ at $5 \times 10^{-5} \mathrm{~mol}$ $1^{-1}$ ARS (at molar ratio 1:1 and $\mathrm{pH} 1.5$ ) and the curve reaches a plateau and then gradually falls above $20 \times 10^{-5} \mathrm{~mol} \mathrm{l}^{-1}$ ARS (at molar ratio $1: 4, \mathrm{Zr}$ :ARS). With respect to hafnium, the floatability gradually increases as ARS is increased reaching maximum separation $(100 \%)$ at a molar ratio of 1:4 for Hf:ARS and the separation percentage is not affected in spite of increasing ARS concentration. Such data agree with those found in the literature in which a 1:1 complex is formed at low $\mathrm{pH}$ values and 1:4 molar ratio at higher $\mathrm{pHs}$.

The data clearly indicate that complete separation of hafnium requires four folds of ARS and the excess does not cause trouble. An equivalent quantity of ARS is enough for complete separation of zirconium, in which the excess of the former over 4 folds of $\mathrm{Zr}(\mathrm{IV})$ significantly affects the separation efficiency. This should be taken into consideration during the separation of the two analytes individually (as shown from Fig. 2). On the other hand, selective separation of the two analytes present in combination (Fig. 1) or in the presence of different matrices, excess of ARS has no effect on the separation efficiency. Accordingly, the selected concentration of ARS for further experiments was $2 \times 10^{-4} \mathrm{~mol} \mathrm{l}^{-1}$. 


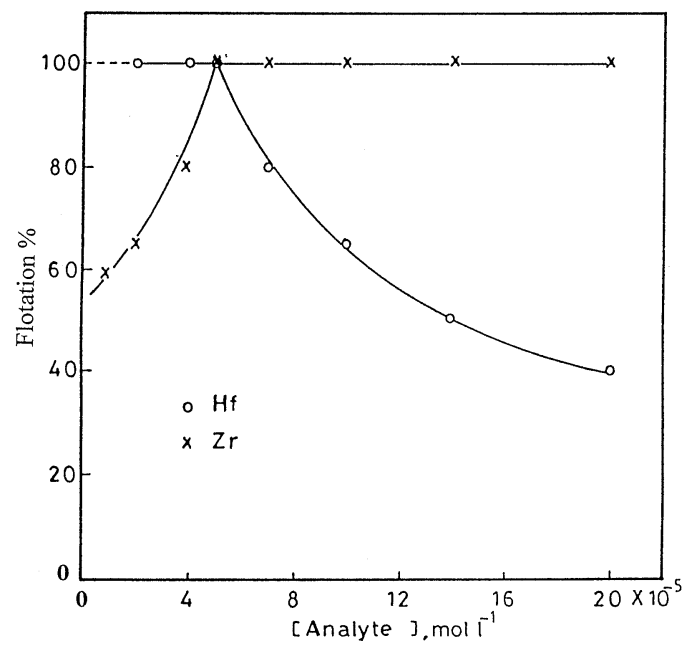

Fig. 3 Floatability of different concentration of $\mathrm{Zr}(\mathrm{IV})$ at $\mathrm{pH} 1.5$ and $\mathrm{Hf}(\mathrm{IV})$ at $\mathrm{pH} 6$ in the presence of $2 \times 10^{-4} \mathrm{~mol} \mathrm{l}^{-1}$ ARS using $2 \times$ $10^{-4} \mathrm{~mol} \mathrm{l}^{-1} \mathrm{HOL}$

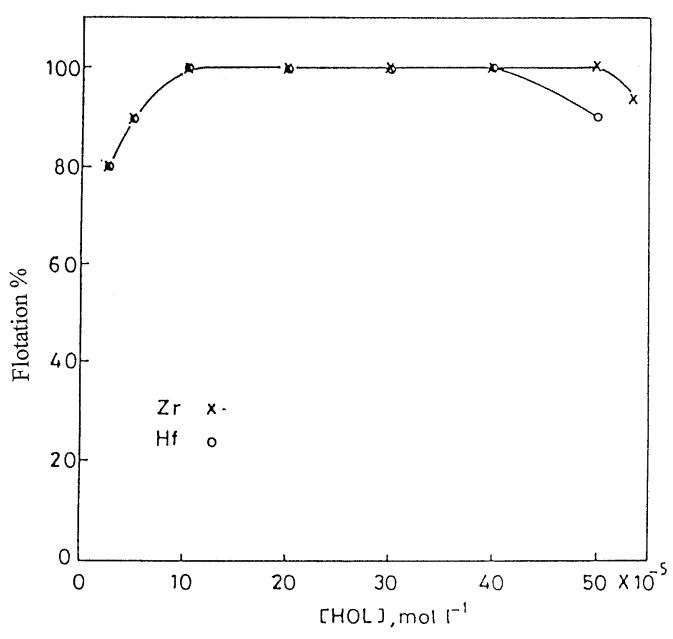

Fig. 4 Floatability of $\mathrm{Zr}(\mathrm{IV})$ at $\mathrm{pH} 1.5$ and $\mathrm{Hf}(\mathrm{IV})$ at $\mathrm{pH} 6$ in the presence of $2 \times 10^{-4} \mathrm{~mol} \mathrm{l}^{-1}$ ARS at different HOL concentration.

To confirm the data in Fig. 2, another series of experiments were carried out to float different solutions containing variable amounts of $\mathrm{Zr}(\mathrm{IV})$ ( $\mathrm{pH} 1.5)$ or $\mathrm{Hf}(\mathrm{IV})(\mathrm{pH} \mathrm{6)}$ to cover the different ratios with ARS $\left(2 \times 10^{-4} \mathrm{~mol} \mathrm{l}^{-1}\right)$ using $2 \times 10^{-4} \mathrm{~mol}$ $1^{-1}$ HOL. These are graphically represented in Fig. 3. In case of zirconium (curve $\times$ ) the separation percentage is reached $100 \%$ in the concentration range $5-20 \times 10^{-5} \mathrm{~mol} \mathrm{l}^{-1}$ corresponds to 1:1 - 1:4 for $\mathrm{Zr}$ :ARS. Under $5 \times 10^{-5} \mathrm{~mol}^{-1}$ concentration level of zirconium (1:4 molar ratio of $\mathrm{Zr}$ :ARS) the separation efficiency is decreased owing to the presence of excess ARS. Concerning Hf (curve O), the floatability is $100 \%$ up to $5 \times 10^{-5}$ mol $1^{-1}$ of $\mathrm{Hf}(\mathrm{IV})$ (1:4 or more with respect to ARS) and the floatability decreases with increasing Hf concentration over $5 \times$ $10^{-5} \mathrm{~mol} \mathrm{l^{-1 }}$, due to insufficient quantity of ARS required for complete complexation.

To study the effect of surfactant concentration on the floatability and separation of $5 \times 10^{-5} \mathrm{~mol} \mathrm{l}^{-1} \mathrm{Zr}(\mathrm{IV})$ (at $\mathrm{pH} 1.5$ ) or $\mathrm{Hf}(\mathrm{IV})$ (at $\mathrm{pH} 6$ ) in presence of $2 \times 10^{-4} \mathrm{~mol} \mathrm{l}^{-1} \mathrm{ARS}$, various experiments were carried out. As shown in Fig. 4, the flotation efficiency increases to its maximum value $(\approx 100 \%)$ at $1 \times 10^{-4}$ mol $1^{-1}$ of HOL and remains constant over a wide range of HOL

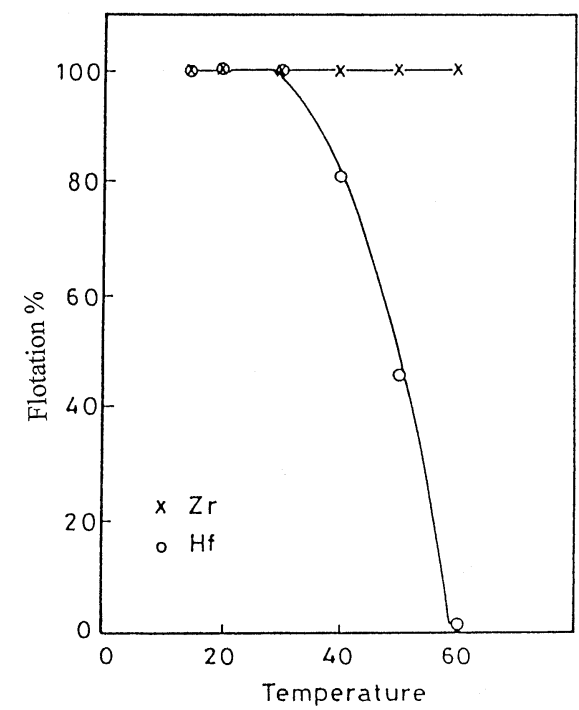

Fig. 5 Effect of temperature on floatability of $5 \times 10^{-5} \mathrm{~mol} \mathrm{l}^{-1}$ $\mathrm{Zr}(\mathrm{V})$ at $\mathrm{pH} 1.5$ and $\mathrm{Hf}(\mathrm{IV})$ at $\mathrm{pH} 6$ in the presence of $2 \times 10^{-4} \mathrm{~mol}$ $\mathrm{l}^{-1}$ ARS using $2 \times 10^{-4} \mathrm{~mol} \mathrm{l}^{-1} \mathrm{HOL}$.

concentration. Hence, $2 \times 10^{-4} \mathrm{~mol} \mathrm{l}^{-1}$ of HOL was fixed throughout all measurements for separation and determination of zirconium and hafnium.

Under the recommended conditions selected from previous experiments for each element, zirconium or hafnium, ARS and HOL were either cooled or heated to the same temperature. The ARS and HOL were quickly poured into each analyte at time zero. The solutions were introduced into two flotation cells jacketed with $1 \mathrm{~cm}$ thick fiberglass insulation. The previous procedure was then followed. It was found that the floatability and separation of $\mathrm{Zr}$-ARS complex were not markedly affected by raising the temperature up to $60^{\circ} \mathrm{C}$. On the other hand, no effect on the separation of Hf-ARS complex was observed up to $35^{\circ} \mathrm{C}$ and over such temperature the separation efficiency is gradually decreased and completely diminished at $60^{\circ} \mathrm{C}$ (Fig. 5). Accordingly, all measurements were carried out at room temperature $\left(\approx 25^{\circ} \mathrm{C}\right)$.

The possibility of the application of this procedure in selective separation of traces of $\mathrm{Zr}(\mathrm{IV})$ and $\mathrm{Hf}(\mathrm{IV})$ depends on the effect of foreign ions. Possible interferences were looked for by taking up $5 \times 10^{-5} \mathrm{~mol}^{-1}$ of each analyte and ARS by the recommended procedure in the presence of various ions. The $\mathrm{pH}$ of the sample solution was firstly adjusted to 1.5 to separate zirconium then raised to 6 to separate hafnium. The data are presented in Table 1. It is clear that all the investigated interfering ions have no effect on the determination of zirconium even on using $2 \times 10^{-4} \mathrm{~mol}^{-1}$ ARS. With respect to hafnium, $\mathrm{Ca}, \mathrm{Mg}, \mathrm{Sr}, \mathrm{Ba}, \mathrm{Pb}, \mathrm{Zn}, \mathrm{UO}_{2}(\mathrm{II}), \mathrm{Hg}, \mathrm{Cd}, \mathrm{Si}$ and $\mathrm{Li}$ have no effect on using $2 \times 10^{-4} \mathrm{~mol} \mathrm{l}^{-1}$ ARS, whereas the rest of the investigated ions are markedly interfering. However these effects can be completely eliminated by increasing the amount of ARS $\left(2 \times 10^{-3} \mathrm{~mol} \mathrm{l}^{-1}\right)$ to cover the requirements of complexation of the foreign ions. The problem is still present from $\mathrm{Pt}, \mathrm{Au}, \mathrm{Pd}$ and $\mathrm{V}$ on hafnium even by using excess of ARS. Fortunately such elements are not involved in real samples of zirconium and hafnium.

Sodium, potassium, calcium and magnesium as chloride, nitrate, sulfate, perchlorate and iodide salts were added during the flotation separation of zirconium and hafnium under the recommended conditions, to study the effect of ionic strength. 
Table 1 Effect of some foreign ions on the separation and determination of $5 \times 10^{-5} \mathrm{~mol} \mathrm{l}^{-1}$ of $\mathrm{Zr}(\mathrm{IV})$ at $\mathrm{pH} 1.5$ and $\mathrm{Hf}(\mathrm{IV})$ at pH 6 in the presence of $2 \times 10^{-4} \mathrm{~mol} \mathrm{l}^{-1} \mathrm{ARS}$, using $2 \times 10^{-4} \mathrm{~mol}^{-1} \mathrm{HOL}$

\begin{tabular}{lrrrrr}
\hline \multicolumn{1}{c}{ Foreign ion } & $\begin{array}{c}\text { Conc. } \\
\text { ppm }\end{array}$ & $\mathrm{Zr}^{\mathrm{b}}$ & $\mathrm{Hf}^{\mathrm{b}}$ & $\mathrm{Zr}^{\mathrm{c}}$ & $\mathrm{Hf}^{\mathrm{c}}$ \\
\hline $\mathrm{Co}, \mathrm{Cu}, \mathrm{Ni}, \mathrm{Mn}, \mathrm{Cr}, \mathrm{Sc}$ & 100 & 100 & 60 & 100 & 98 \\
$\mathrm{Al}, \mathrm{Fe}$ & 500 & 100 & 40 & 100 & 100 \\
$\mathrm{Mo}, \mathrm{W}, \mathrm{As}$ & 100 & 100 & 91 & 100 & 100 \\
$\mathrm{Pt}, \mathrm{Pd}, \mathrm{Au}, \mathrm{V}$ & 100 & 100 & 50 & 100 & 85 \\
Y, La, Th & 200 & 100 & 60 & 100 & 100 \\
$\mathrm{Ca}, \mathrm{Mg}, \mathrm{Sr}, \mathrm{Ba}, \mathrm{Pb}, \mathrm{Zn}$, & 1000 & 100 & 100 & 100 & 100 \\
$\mathrm{UO}_{2}(\mathrm{II}), \mathrm{Hg}, \mathrm{Cd}, \mathrm{Si}, \mathrm{Li}$ & & & & & \\
\hline
\end{tabular}

a. Tolerance limit (maximum amount added).

b. Using $2 \times 10^{-4} \mathrm{~mol} \mathrm{l}^{-1}$ ARS.

c. Using $2 \times 10^{-3} \mathrm{~mol} \mathrm{l}^{-1}$ ARS.

It was found that most of these salts (even up to $0.1 \mathrm{~mol} \mathrm{l}^{-1}$ concentration level) have no effect on the flotation efficiency of both hafnium and zirconium.

\section{Separation mechanism}

In the studies concerning the separation via flotation, the role of surfactant is very important. The nature of interaction between oleic acid surfactant and the complex formed (Zr-ARS or Hf-ARS) must be studied to approach the actual mechanism of flotation. The proposed mechanism may proceed by forming a hydrogen bond between the hydrophilic part of HOL and the active sites in the ligand complex or by interaction between oleic acid and the complex, formed in solution, through a coordinate bond forming a self-floatable species (Analyte-ARSHOL). In both cases, the hydrophobic part of the surfactant attached to the air bubbles and floats, separating the analyte containing species. In this investigation the two possibilities are observed in the case of zirconium whereas, in case of hafnium, another proposal should be pointed out. In this concern some observations and experiments were considered: 1) Elemental analyses of the complexes isolated for zirconium and hafnium in the absence and presence of HOL proved that HOL is an integral part of zirconium complex isolated in presence of HOL, whereas that of Hf is free from HOL. 2) The floated complex of hafnium has the same color (reddish violet) as that obtained in the aqueous solution, whereas a change of color was observed for zirconium complex isolated in HOL layer (pink) from that formed in aqueous solution. 3) The unstability of the species formed in the presence of HOL in the case of hafnium may be due to the decomposition of the very weak forces between oleic acid and Hf-ARS complex at relatively low temperatures above $35^{\circ} \mathrm{C}$. On the other hand, the stability of zirconium species separated in HOL layer, even at relatively high temperatures $\sim 60^{\circ} \mathrm{C}$, reflect that $\mathrm{HOL}$ is an integral part of solid separated species. 4) Two parallel experiments were carried out to float hafnium and zirconium, each individually, under the same recommended conditions. It was found that, the minimum time required for complete separation of each analyte in the scum layer is $1 \mathrm{~min}$. Also, a few hours $(\sim 3 \mathrm{~h})$ are required for drawback of Hf-ARS complex from the scum layer to the mother liquor, letting the former remaining as HOL only. On the other hand, in the case of zirconium no drawback was observed even after few weeks ( $\sim 4$ weeks). This reflects that the scum layer in the case of zirconium may consist of $\mathrm{Zr}$, ARS and HOL in one chemical form and 5) Fig. 6 shows that the i.r. spectrum of $\mathrm{ZrO}^{2+}$-ARS compound isolated in the aqueous solution includes the two bands due to $v(\mathrm{CO})$ groups in ARS,

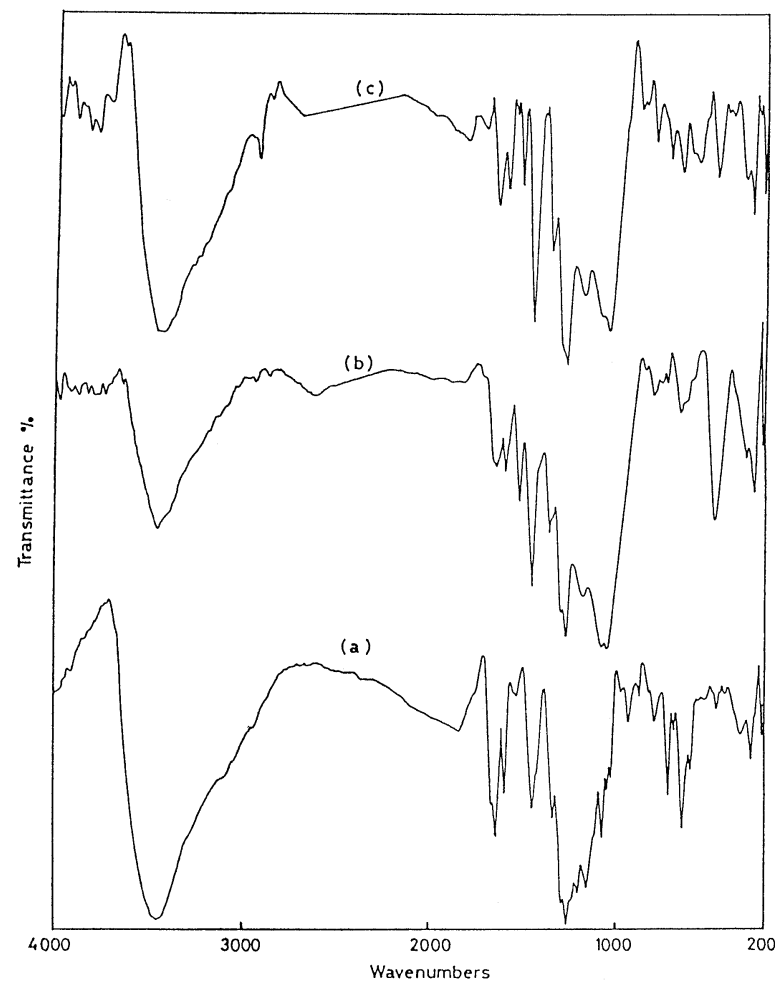

Fig. 6 Infrared spectra of (a) ARS in $\mathrm{KBr}$, (b) $\mathrm{Zr}$-ARS isolated in aqueous solution in $\mathrm{KBr}$ and (c) $\mathrm{Zr}$-ARS-HOL isolated in oleic acid in $\mathrm{KBr}$.<smiles></smiles>

Structure 1 Schematic diagram of zirconium sublate.

indicating that those groups are not taking part in coordination. The intensity of $v(\mathrm{OH})$ band decreases on complexation with the appearance of only one strong at $3451 \mathrm{~cm}^{-1}$. This band may be due to $v(\mathrm{OH})_{2}$ as the coordinated water, while the lowering in intensity is attributed to the deprotonation of the $\mathrm{OH}$ groups. The i.r. spectrum of the $\mathrm{Zr}$-complex isolated in the presence of oleic acid is similar to that previously aforementioned except: i) the appearance of a new band at $1700 \mathrm{~cm}^{-1}$ suggests the participation of oleic acid in complex formation; this band is due to $v(\mathrm{CO})$ of $\mathrm{COOH}$ group; ii) the band centered at 3450 $\mathrm{cm}^{-1}$ turns broad with the appearance of some shoulders; the broadness may be due to the existence of $v(\mathrm{OH})$ vibration of $\mathrm{COOH}$ group; iii) the appearance of new bands at 2870 and $2920 \mathrm{~cm}^{-1}$, which are due to $v(\mathrm{CH})$ vibrations of the aliphatic carbons in oleic acid; iv) the bands observed at 1800 and 1980 $\mathrm{cm}^{-1}$ are due to $v(\mathrm{O}-\mathrm{H})$ vibration as the intramolecular hydrogen bonding. This may suggest that oleic acid is taking part in coordination with the $\mathrm{ZrO}^{2+}$ ion with the presence of hydrogen bonding. So the sublate structure in case of zirconium may be represented as shown in Structure 1. On the other hand, the data 
in Fig. 7 show no obvious differences between the i.r. spectrum of Hf complex isolated in aqueous or in HOL solutions, reflecting that no coordination or hydrogen bonds are formed between Hf-ARS complex and HOL. In such case, the

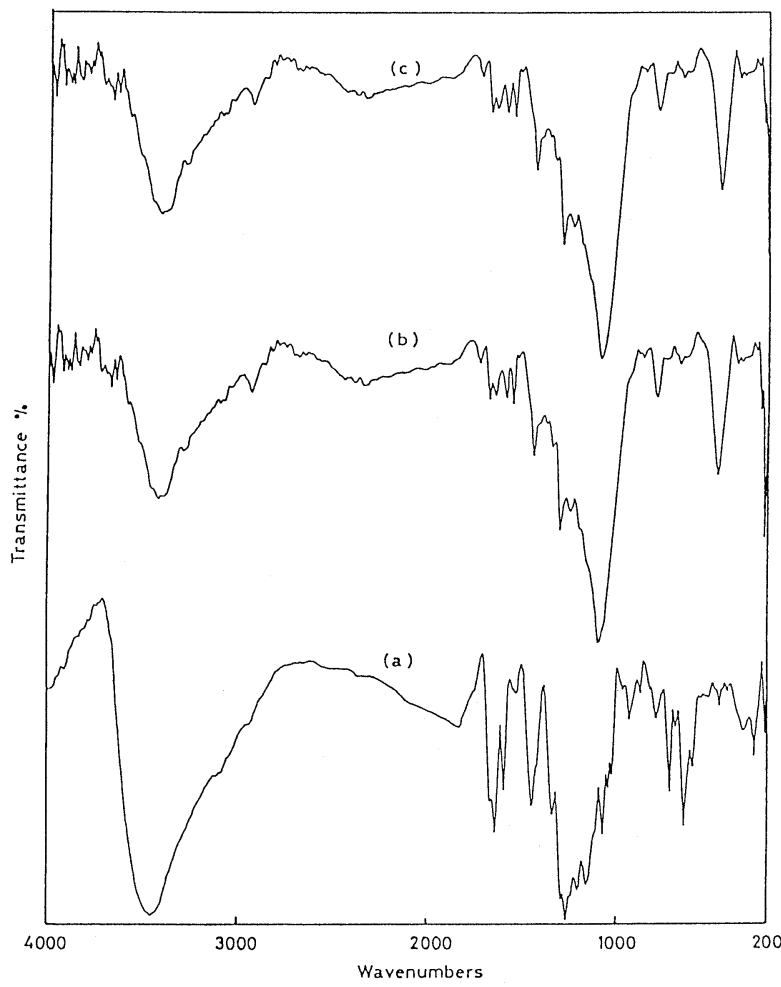

Fig. 7 Infrared spectra of (a) ARS in $\mathrm{KBr}$, (b) Hf-ARS isolated in aqueous solution in $\mathrm{KBr}$ and (c) Hf-ARS-HOL isolated in oleic acid in $\mathrm{KBr}$.

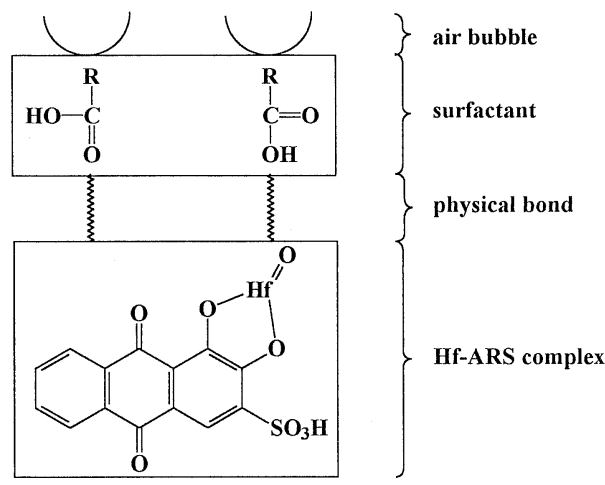

Structure 2 Schematic diagram of hafnium sublate separation mechanism may be due to the formation of physical force like van der Waals force. In conclusion all the mentioned studies confirm that separation of hafnium is, most probably, due to physical interaction between HOL surfactant and HfARS complex (Structure 2).

Application: separation and determination of $\mathrm{Zr}(\mathrm{IV})$ and $H f(I V)$ in real, simulated andwater samples

Exactly $0.25 \mathrm{~g}$ of solid real sample was completely dissolved in a Teflon beaker with a mixture of acids $(45 \mathrm{ml} \mathrm{HF}, 15 \mathrm{ml}$ $\mathrm{H}_{2} \mathrm{SO}_{4}$ and $5 \mathrm{ml} \mathrm{HNO}_{3}$ ). After complete dissolution, the solution was evaporated till dryness. The residue was dissolved

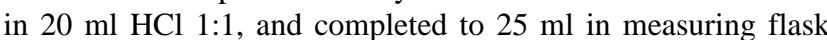
using doubly distilled water. A $0.5-\mathrm{ml}$ portion of this solution was taken and $3 \mathrm{ml}$ of $10^{-2}$ mol 1-1 ARS were added. The $\mathrm{pH}$ was adjusted to $1.5-2$ and the mixture was quantitatively transferred into a flotation cell and completed to $10 \mathrm{ml}$ with doubly distilled water. The cell was shaken for a few seconds, to ensure complete complexation, then $3 \mathrm{ml} \mathrm{HOL} 2 \times 10^{-4} \mathrm{~mol}$ $1^{-1}$ were added and the cell was inverted upside down by hand twenty times for complete flotation. The same previous steps for flotation, metal elution and spectrophotometric determination were carried out using Arsenazo III as a blank in the test solution for the spectrophotometric measurements. The results are listed in Table 2 . The effects of numerous ions, which are naturally allied with $\mathrm{Zr}(\mathrm{IV})$ and $\mathrm{Hf}(\mathrm{IV})$ in their real samples, on the efficiency of separation and determination of the analytes in synthetic mixtures are summarized in Table 3. To investigate the applicability of this procedure to natural water samples, the recoveries of known amounts of both $\mathrm{Zr}(\mathrm{IV})$ and $\mathrm{Hf}(\mathrm{IV})$ added to distilled, domestic, tank and river water samples were examined by the above procedure. To $20 \mathrm{ml}$ aliquots of clear uncontaminated, filtered water samples, different concentrations of $\mathrm{Zr}(\mathrm{IV})$ and $\mathrm{Hf}(\mathrm{IV})$ were introduced and $2 \mathrm{ml}$ of $10^{-2} \mathrm{~mol} \mathrm{l}^{-1}$ ARS were added. The same previous steps for flotation, metal elution and spectrophotometric determination were carried out. The results are given in Table 4. The data demonstrate that the technique is applicable to separate hafnium and zirconium in different natural water samples and had a satisfactory recovery of them.

\section{References}

1. A. I. Busev, V. G. Tiptsova, and V. M. Ivanov, "Analytical Chemistry of Rare Elements", 1978, Mir Publishers, Moscow, 157.

2. A. G. Sharpe, "Inorganic chemistry", 2nd ed., 1986, Longman Group Ltd., Singapore, 623.

3. F. A. Cotton and G. Wilkinson, "Advanced Inorganic Chemistry", 3rd ed., 1971, Wiley Eastern Limited, New Delhi, Bangalore, 928.

4. J. C. Bailer, H. J. Emeleus, R. Nyholm, and A. F. Trotman-

Table 2 Comparative results for analysis of $\mathrm{Zr}(\mathrm{IV})$ at $\mathrm{pH} 1.5$ and $\mathrm{Hf}(\mathrm{IV})$ at $\mathrm{pH} 6$ in some ore samples using $3 \times 10^{-3} \mathrm{~mol} \mathrm{l}^{-1} \mathrm{ARS}$ and $2 \times$ $10^{-4} \mathrm{~mol} \mathrm{l}^{-1} \mathrm{HOL}$

\begin{tabular}{|c|c|c|c|c|c|c|}
\hline \multirow[b]{2}{*}{ Ore name } & \multicolumn{3}{|c|}{$\mathrm{Zr}, \mathrm{ppm}$} & \multicolumn{3}{|c|}{ Hf, ppm } \\
\hline & Certified & $\begin{array}{l}\text { Present } \\
\text { method }\end{array}$ & Recovery, \% & Certified & $\begin{array}{l}\text { Present } \\
\text { method }\end{array}$ & Recovery, \% \\
\hline $\begin{array}{l}20283 \text { MAL1 NIM-G } \\
\text { Granite }\end{array}$ & 300 & 299.3 & 99.8 & 12 & 11.7 & 97.5 \\
\hline $\begin{array}{c}20283 \text { MAL1 NIM-L } \\
\text { Lujavrite }\end{array}$ & $\begin{array}{l}11 \times 10^{3} \\
(1.100 \%)\end{array}$ & $\begin{array}{c}11.043 \times 10^{3} \\
(1.104 \%)\end{array}$ & 100.4 & 190 & 191.2 & 100.6 \\
\hline
\end{tabular}


Table 3 Recovery of $5 \mathrm{ppm} \mathrm{Zr(IV)}$ at $\mathrm{pH} 1.5$ and $\mathrm{Hf}(\mathrm{IV})$ and $\mathrm{pH} 6$ from different synthetic mixtures in the presence of $2 \times 10^{-3}$ mol $1^{-1}$ ARS using $2 \times 10^{-4} \mathrm{~mol} \mathrm{l}^{-1} \mathrm{HOL}$

\begin{tabular}{|c|c|c|c|c|c|c|c|c|c|c|}
\hline \multirow{2}{*}{$\begin{array}{c}\text { Synthetic mixtures } \\
50 \mathrm{ppm} \text { of each element }\end{array}$} & \multicolumn{2}{|c|}{ Found } & \multicolumn{2}{|c|}{ Abs. error } & \multicolumn{2}{|c|}{ R. error } & \multicolumn{2}{|c|}{$\mathrm{SD} \pm$} & \multicolumn{2}{|c|}{ RSD } \\
\hline & $\mathrm{Zr}$ & Hf & $\mathrm{Zr}$ & $\mathrm{Hf}$ & $\mathrm{Zr}$ & $\mathrm{Hf}$ & $\mathrm{Zr}$ & $\mathrm{Hf}$ & $\mathrm{Zr}$ & Hf \\
\hline 1. $\mathrm{Ca}+\mathrm{Th}+\mathrm{Y}+\mathrm{Co}$ & 5.023 & 5.03 & 0.023 & 0.03 & +0.46 & +0.6 & 0.022 & 0.014 & 0.44 & 0.28 \\
\hline 2. $\mathrm{Cd}+\mathrm{Y}+\mathrm{La}+\mathrm{Cu}$ & 5.027 & 5.037 & 0.027 & 0.037 & +0.54 & +0.74 & 0.022 & 0.033 & 0.44 & 0.66 \\
\hline 3. $\mathrm{Si}+\mathrm{Th}+\mathrm{La}+\mathrm{Cr}$ & 5.021 & 5.028 & 0.021 & 0.028 & +0.42 & +0.056 & 0.01 & 0.018 & 0.2 & 0.36 \\
\hline 4. $\mathrm{Zn}+\mathrm{Mg}+\mathrm{Ba}+\mathrm{Co}$ & 5.03 & 5.013 & 0.03 & 0.013 & +0.6 & +0.26 & 0.028 & 0.013 & 0.56 & 0.26 \\
\hline 5. $\mathrm{Cd}+\mathrm{Zn}+\mathrm{Al}+\mathrm{Fe}$ & 5.033 & 5.037 & 0033 & 0.37 & +0.66 & +0.74 & 0.033 & 0.026 & 0.66 & 0.52 \\
\hline 6. $\mathrm{Li}+\mathrm{Ni}+\mathrm{Mn}+\mathrm{Fe}$ & 5.02 & 5.043 & 0.02 & 0.043 & +0.4 & +0.86 & 0.024 & 0.014 & 0.48 & 0.28 \\
\hline 7. $\mathrm{Pb}+\mathrm{Fe}+\mathrm{Al}+\mathrm{Mo}$ & 5.033 & 5.043 & 0.033 & 0.043 & +0.66 & +0.86 & 0.014 & 0.033 & 0.28 & 0.65 \\
\hline 8. $\mathrm{Sc}+\mathrm{Th}+\mathrm{UO}_{2}(\mathrm{II})+\mathrm{Sr}$ & 4.995 & 5.01 & 0.005 & 0.01 & -0.1 & +0.2 & 0.018 & 0.042 & 0.36 & 0.84 \\
\hline 9. $\mathrm{W}+\mathrm{Pb}+\mathrm{Al}+\mathrm{Ba}$ & 5.01 & 5.025 & 0.01 & 0.025 & +0.2 & +0.5 & 0.042 & 0.007 & 0.84 & 0.14 \\
\hline 10. $\mathrm{Mg}+\mathrm{UO}_{2}(\mathrm{II})+\mathrm{La}+\mathrm{Pb}$ & 4.993 & 5.033 & 0.007 & 0.033 & -0.14 & +0.66 & 0.015 & 0.024 & 0.30 & 0.48 \\
\hline
\end{tabular}

Table 4 Recovery of $\mathrm{Zr}(\mathrm{IV})$ at $\mathrm{pH} 1.5$ and $\mathrm{Hf}(\mathrm{IV})$ at $\mathrm{pH} 6$ added to natural water Nile samples using $2 \times 10^{-3} \mathrm{~mol}^{-1}$ ARS in the presence of $2 \times 10^{-4} \mathrm{~mol} \mathrm{l}^{-1} \mathrm{HOL}$

\begin{tabular}{lccc}
\hline \multirow{2}{*}{$\begin{array}{c}\text { Type of water } \\
\text { location }\end{array}$} & $\begin{array}{c}\text { Analyte added } \\
10^{-4} \mathrm{~mol}^{-1}\end{array}$ & $\mathrm{Zr}(\mathrm{IV})$ & $\mathrm{Hf}(\mathrm{IV})$ \\
\cline { 3 - 4 } & & $100 \pm 0.0$ & $100 \pm 0.0$ \\
Bidistilled water & 0.5 & $100 \pm 0.0$ & $100 \pm 0.0$ \\
& 1 & $100 \pm 0.2$ & $100 \pm 0.3$ \\
Domestic water & 0.5 & $100 \pm 0.2$ & $100 \pm 0.5$ \\
(Mansoura City) & 1 & $100 \pm 0.3$ & $100 \pm 0.3$ \\
Tank water & 0.5 & $100 \pm 0.4$ & $100 \pm 0.3$ \\
(Mansoura City) & 1 & $100 \pm 0.2$ & $100 \pm 0.4$ \\
Nile water & 0.5 & $100 \pm 0.3$ & $100 \pm 0.3$ \\
(Mansoura City) & 1 & $100 \pm 0.5$ & $100 \pm 0.2$ \\
Nile water & 0.5 & $100 \pm 0.4$ & $100 \pm 0.4$ \\
(Belkas City) & 1 & $100 \pm 0.4$ & $100 \pm 0.4$ \\
Nile water & 0.5 & $100 \pm 0.2$ & $100 \pm 0.5$ \\
(Talkha City) & 1 & & \\
\hline
\end{tabular}

Dickenson, "Comprehensive Inorganic Chemistry", 1975, Vol. 3, Pergamon Press, Oxford, New York, 419.

5. I. V. Vincrov, Russ. Chem. Rev., 1967, 36, 522.

6. E. A. Jdid, P. Blazy, A. Mahamdou, and R. Durand, Sep. Sci. Technol., 1990, 25, 701.

7. M. T. Ityokumbul, W. Bulani, and N. Kasaric, Water Sci. Technol., 1987, 19, 323.

8. P. Pakalns, Anal. Chem. Acta, 1969, 44, 73.

9. H. E. Zittel and T. M. Florence, Anal. Chem., 1967, 39, 320.
10. J. P. Young, J. R. French, and J. C. White, Anal. Chem., 1953, 30, 422.

11. J. P. Young and J. C. White, Talanta, 1958, 1, 263.

12. K. F. Karlysheva, A. V. Koshel, and L. F. Vashul, Ukr. Khim. Zh., 1972, 38, 493.

13. I. S. Mustafin and V. S. Shchukina, Tr. Komis, Po Analit. Khim. Akad. Nauk SSSR, 1969, 17, 345.

14. R. T. Van Santen, J. H. Schlewitz, and C. H. Toy, Anal. Chim. Acta, 1965, 33, 593.

15. D. J. Wilson and A. N. Clarke, "Development in Foam Flotation", 1983, Dekker, New York.

16. S. D. Huang, T. P. Vu, C. H. Ling, G. L. Sheu, C. C. Wu, and M. H. Cheng, J. Colloid Interface Sci., 1988, 124, 666.

17. M. Hiraide and A. Mizuike, Bull. Chem. Soc. Jpn., 1975, 48, 3753.

18. A. Mizuike, "Enrichment Techniques for Inorganic Trace Analysis", 1983, Springer Verlag, New York.

19. M. A. Kabil, Fresenius. J. Anal. Chem., 1994, 348, 246.

20. S. E. Ghazy and M. A. Kabil, Analusis, 1995, 23, 117.

21. M. A. Kabil and S. E. Ghazy, Ind. J. Chem. Technol., 1994, $1,108$.

22. M. A. Kabil, S. E. Ghazy, A. M. Abeidu, and N. M. ElMetwaly, Sep. Sci. Technol, 1995, 30, 3787.

23. M. A. Kabil, S. E. Ghazy, M. R. Lasheen, A. M. Shallaby, and N. S. Amar, Fresenius. J. Anal. Chem., 1996, 354, 371.

24. M. A. Kabil, J. Anal. At. Spectrom., 1995, 10, 733.

25. M. A. Kabil, S. E. Ghazy, A. A. El-Asmy, and Y. E. Sherif, Fresenius. J. Anal. Chem., 1997, 357, 401.

26. D. E. Green, Anal. Chem., 1948, 20, 370.

27. O. Gubeli and A. Jacob, Helv. Chim. Acta, 1955, 38, 1026. 